\title{
Exploring Alternative Octane Specification Methods for Improved Gasoline Knock Resistance in Spark-Ignition Engines
}

\author{
Amir F. N. Abdul-Manan ${ }^{1 *}$, Gautam Kalghatgi ${ }^{2}$ and Hassan Babiker ${ }^{1}$ \\ ${ }^{1}$ Saudi Aramco, Strategic Transport Analysis Team, Fuel Technology R\&D, Research \& Development Center, Dhahran, \\ Saudi Arabia, ${ }^{2}$ Saudi Aramco, Fuel Technology R\&D, Research \& Development Center, Dhahran, Saudi Arabia
}

Different octane specification methods were evaluated under rising ethanol blending volumes by adopting a refinery economics model to represent a region in the U.S. It was demonstrated that the traditional octane specification methods, such as the Anti-knock Index (AKI) used in the U.S., or the Research Octane Number (RON) and Motor Octane Number (MON) used in the EU, can lead to counterintuitive drop in octane sensitivity with increased availability of ethanol. This is undesirable for modern gasoline engines

OPEN ACCESS

Edited by:

Mingfa Yao,

Tianjin University, China

Reviewed by:

Hu Wang,

Tianjin University, China

Shiyou Yang,

Ford Motor Company, United States

Ming Jia,

Dalian University of Technology (DUT),

China

${ }^{*}$ Correspondence:

Amir F. N. Abdul-Manan

amir.abdulmanan@aramco.com

Specialty section:

This article was submitted to Engine and Automotive Engineering,

a section of the journal

Frontiers in Mechanical Engineering

Received: 07 June 2018 Accepted: 27 November 2018 Published: 10 December 2018

Citation:

Abdul-Manan AFN, Kalghatgi G and Babiker H (2018) Exploring Alternative

Octane Specification Methods for Improved Gasoline Knock Resistance

in Spark-Ignition Engines.

Front. Mech. Eng. 4:20.

doi: 10.3389/fmech.2018.00020 that require fuels with high $\mathrm{RON}$ and low MON, but it is a consequence of how a refinery reformulates the gasoline blendstock, resulting in more naphtha being used in the final composition. The use of a new specification method based on octane index $(\mathrm{Ol})$, with engine constant $K=-1$, internalizes the diminishing role that MON plays in modern engines, thus ensures that the desirable anti-knock quality is being met either through higher $\mathrm{RON}$ and/or higher sensitivity. Initial assessment suggests a potential engine efficiency benefit $(\sim 1.5 \%)$ to be gained simply by switching from an AKI-based specification method to an equivalent Ol-based method.

Keywords: octane, spark-ignition, anti-knock, gasoline, efficiency, fuel specification, refinery

\section{BACKGROUND}

The evolution of the automobiles in the last century (Splitter et al., 2016), and the parallel adaption of petroleum refineries to increasing and shifting demand for fuels (Gudde, 2017), have allowed for significant progress to be achieved within the transport sector (EPA, 2014). The internal combustion (IC) engine, which accounts for more than $99 \%$ of automotive drivetrains, has primarily been fueled by petroleum-derived hydrocarbons throughout the history of the automobile (BP, 2014; ExxonMobil, 2015; IEA, 2017); though alternative fuels and powertrains have been fast growing in the last decades (IEA, 2017). The transportation landscape today is undergoing tremendous changes, mainly driven by legislative requirements aimed at reducing tailpipe pollutant emissions, improving vehicle efficiency and mitigating the impact of transportation on global climate change. Equally important, consumers are increasingly demanding for vehicles with improved performance and drivability, and better affordability. This has led to technological advancements in many aspects of engine designs, combustion control and after-treatment systems that can deliver improved efficiency and lower emissions. The ability of fuels to co-evolve to enable advanced engines is central to the future of a sustainable transport solution. This has been recognized since the early Twentieth century with documented scientific inquiries on the 
relationships between fuels and engines, and their effects on auto-ignition, geometric compression ratio and the performances of spark-ignition (SI) engines (Horning, 1923; Young and Holloway, 1924).

Gasoline and diesel, the two most common fuels used in IC engines, are complex mixtures of hydrocarbons comprising of refinery streams that have been chemically upgraded to meet the stringent quality and emission requirements of modern engines worldwide. Conventional diesel fuels are typically designed to autoignite readily in a compression ignition (CI) engine. While CI engines are much more efficient than SI engines, they suffer from higher engine-out emissions of NOx and particulates due to their limited premixing time. To control these pollutant emissions, modern CI engines rely on complicated and costly technologies to overcome the challenges associated with the autoignition tendency of the fuel. It has been proposed that the use of a new lower-octane fuel, comprising of gasolinelike streams, in an efficient CI engine can enable significant improvements to the efficiency and emissions of the transport sector. The engine, also known as GCI (gasoline compression ignition), has been shown to be at least be as efficient and clean as current diesel engines (Kalghatgi and Johansson, 2018). Given that it will be less complicated than contemporary diesel CI engines, it is likely to be cheaper too. Although the new fuel and engine concept has been well-demonstrated, more development work is still required to make it into a practical and sustainable solution for the sector.

Conversely, the octane quality of gasoline, which measures the ability of the fuel to resist autoignition, is a highly desirable property for a spark ignition (SI) engine. A higher octane gasoline can enable more efficient SI engines through the use of increased compression ratio, or engine downsizing and downspeeding. Often this allows engines to operate at higher break mean effective pressure (BMEP) levels, typically limited by the onset of engine knock. Hence, the availability of gasoline with improved knock resistance is central to many automakers' strategy to achieve greater fuel efficiency in modern SI fleets (CRC, 2017). In some existing SI vehicles equipped with closedloop knock detection algorithms, the use of a higher octane fuel also allows for the engines to advance their spark timing to enhance performance and efficiency. However, in typical real world driving, the octane appetite of engines varies with the operating conditions and, under most conditions, the octane needs of the engine can be satisfied by modest octane levels (Partridge et al., 2014; Chang et al., 2015). It is only under more severe loads that higher octane fuels are needed to ensure optimal performance and efficiency (Liu et al., 2014). The varying octane needs of the engine, and the fact that higher octane is mostly only needed in a narrow operating region, have given rise to the concept of octane-on-demand (Liu et al., 2014; Partridge et al.,

Abbreviations: AKI, antiknock index; RON, research octane number; MON, motor octane number; OI, octane index; SI, spark-ignition; CI, compression-ignition; GCI, gasoline compression ignition; S, sensitivity; E10, 10\% ethanol 90\% gasoline; E0 neat gasoline; BOB, blendstock for oxygenate blending; FCC, fluid catalytic cracking; bRON, volumetric blending RON for ethanol; bMON, volumetric blending MON for ethanol.
2014; Chang et al., 2015; Morganti et al., 2017). Such an approach allows for the use of low octane for most of the operating regime, and higher octane when it is needed the most. Thus, the concept can still enable a more efficient SI engine but through greater utilization of the available octane. However, more research and development work is still required to advance the technology into a practical commercial solution.

In the meantime, the desire for more efficient engines is increasing the appetite for high octane gasoline. The production of high octane fuel often requires energy intensive processes within the refinery or involves more complex blending operations. The increasing use of bioethanols in gasoline as part of growing renewable fuels mandate worldwide offers an opportunity to simultaneously boost the octane level of the fuel given that ethanol has excellent antiknock quality. However, with the limited supply of advanced generation and sustainably-sourced bioethanol, refiners will be increasingly stretched to satisfy the growing appetite for octane. Researchers within the industry are currently exploring ways to increase the octane production capacity which, amongst others, include the development of novel alternative octane production routes. As an example, SuperButol ${ }^{\mathrm{TM}}$, a novel refinery-derived high octane component comprising of mixed butanol isomers and di-isobutylene, was recently demonstrated at a pilot production scale (Xu and Vogel, 2011; Shaik et al., 2015); and its use in gasoline blends was shown to be compatible with key gasoline specifications (Kalamaras et al., 2017).

Octane specifications worldwide vary considerably between different markets (Table 1). In Europe, EN228 regulates the octane of gasoline by specifying the RON and MON at a minimum of 95 and 85, respectively. This translates to a minimum anti-knock index (AKI, i.e., the average of RON and MON) of 90. This is higher than regular U.S. gasoline, which typically has an AKI of 87. The higher octane level in Europe allows for engines with slightly higher compression ratio and thus, better efficiency than the U.S (Anderson et al., 2012a). In many markets, gasoline with the highest market share would have an octane level of about 92 RON (Table 1), which is still below the EU's minimum octane specification level.

Most countries tend to specify gasoline octane on the basis of AKI, RON, or both RON and MON. As an exception,

TABLE 1 | An overview of current specifications for gasoline knock resistance in 6 key markets globally.

\begin{tabular}{|c|c|c|c|c|c|c|}
\hline & \multicolumn{6}{|c|}{ Current specifications on gasoline octane in key markets } \\
\hline & $\begin{array}{c}\text { EU euro } \\
\text { VI }\end{array}$ & US tier 3 & Brazil & Russia & China V & $\begin{array}{c}\text { India } \\
\text { bharat IV }\end{array}$ \\
\hline $\mathrm{RON}$ & 95 & & & $\begin{array}{c}80 / \mathbf{9 2} / 95 / \\
98\end{array}$ & $\begin{array}{c}89 / 92 / 95 / \\
98\end{array}$ & 91/95 \\
\hline MON & 85 & & 82 & $\begin{array}{l}76 / 83 / \\
85 / 88\end{array}$ & & $81 / 85$ \\
\hline $\begin{array}{l}\mathrm{AKI} \\
(\mathrm{RON}+\mathrm{MON}) / 2\end{array}$ & & $87 / 89 / 91$ & $87 / 91$ & & $\begin{array}{c}84 / 87 / 90 / \\
93\end{array}$ & \\
\hline
\end{tabular}

Octane levels with the highest market share are in bold. U.S. Tier 3-Octane limits are set and regulated at the state level. The industry standard AKI are generally 87/89/91. 
China specifies the RON and AKI of their gasolines. RON and MON scales are based on primary reference fuels (PRFs) mixtures of iso-octane and n-heptane-which is the surrogate fuel we use today within the industry and in most octane specifications worldwide. RON and MON describes the antiknock behavior of practical gasolines only at the RON and MON test conditions, respectively. The existing octane scale has been used within the industry for about 80 years or so, and recently an alternative rating method based on toluene/n-heptane mixtures (toluene reference fuels, TRF) was proposed to better reflect the anti-knock quality of practical gasolines (Kalghatgi et al., 2014). It is well established that the autoignition chemistry of a practical gasoline, which is not a simple binary mixture of iso-octane and n-heptane, is significantly different from that of PRFs.

The true anti-knock quality of gasoline is given by its octane index, OI $=\mathrm{RON}-\mathrm{K} \mathrm{S}$, where $\mathrm{S}=\mathrm{RON}-\mathrm{MON}$, is the sensitivity (Kalghatgi, 2014). $\mathrm{K}$ is an engine constant that depends on the pressure and temperature history of the unburned mixture in the cylinder (Figure 1A). At a given temperature, the RON test has a higher pressure than the MON test; or alternatively, for a given pressure, the temperature of the unburned gas is lower in the RON test compared to the MON test. Effectively, $\mathrm{K}$ acts as a weighting factor between RON and MON; a value of 1.0 means that $\mathrm{OI}=\mathrm{MON}$, while values of 0.5 and 0 lead to OI $=\mathrm{AKI}$, and $\mathrm{OI}=\mathrm{RON}$, respectively. SI engines have become more efficient through the years and this has meant that, for a given temperature of the unburned mixture in the cylinder, the pressure has increased. Consequently, the value of $\mathrm{K}$ has also declined in general (Figure 1B). For instance, when the MON test was first proposed in the late 1920s, engines had a $K$-value close to 1 . The AKI was proposed as a measure of fuel anti-knock quality in the mid-1950s because the engines of that time generally had a $K$-value of 0.5 at the operating conditions most prone to knock. Multiple experimental studies have confirmed that the value of $\mathrm{K}$ has been steadily declining, such that modern engines today have been demonstrated to have negative $K$-values especially under operating conditions where their performances are limited by knock (Kalghatgi, 2001; Mittal and Heywood, 2010; CRC Octane Group, 2011; Prakash et al., 2016; Stradling et al., 2016). This suggests that, for the same RON, fuels with lower MON will actually have better anti-knock quality. Therefore, octane specifications that are still based on MON and AKI, are likely to be less relevant for modern SI engines. In keeping with the evolution of engines, fuels will have to adapt accordingly to enable a more efficient transportation future.

This paper explores an alternative octane specification method based on OI. Refinery assessments were performed to compare and contrast several existing approaches and the implications for gasoline refining. The analysis was conducted using a refinery economics model to represent an average refinery in a U.S. region. This study shows that as ethanol is increasingly being used to meet the octane requirements of modern engines, the sensitivity of the ethanol-gasoline blend can decrease. This is counterintuitive given the high octane sensitivity of ethanol, but it is a result of the way gasoline is being specified in most markets today. Moreover, this demonstrates that gasoline fuel is being pushed in a different direction compared to engine trends, and therefore this study supports prior works that have called into question the relevance of incorporating a minimum MON specification for modern gasolines.

\section{EXPERIMENTAL DETAIL}

A refinery linear-programming (LP) model was developed to represent the refining system in the U.S. Gulf Coast (PADD III). An LP model is a refinery economics optimization model that is already routinely used by most refiners worldwide to guide short-term production plans and inform longer-term investment decisions (Abdul-Manan et al., 2017; Gordillo et al., 2017).

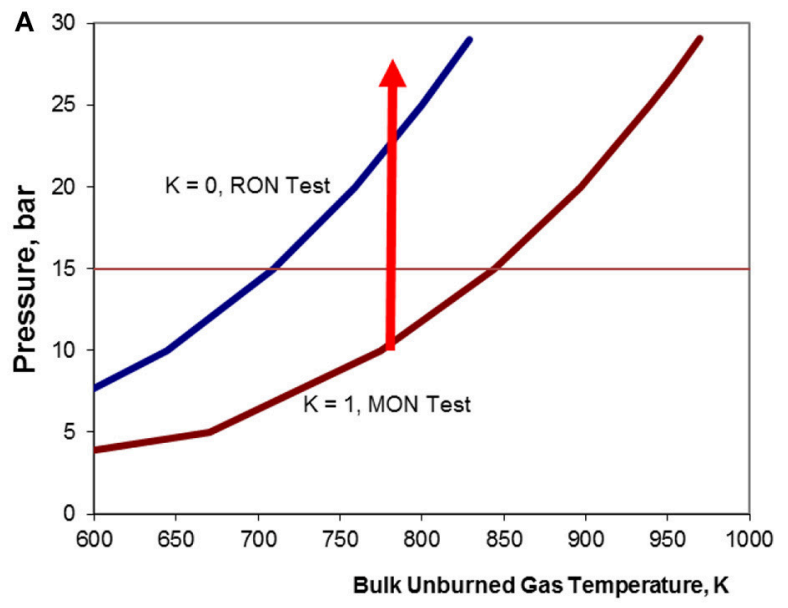

B

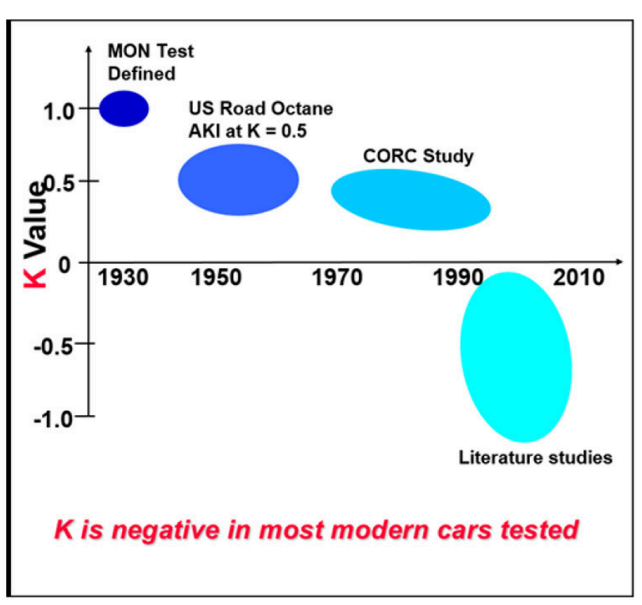

FIGURE 1 | (A) Pressure vs. unburnt gas temperature in the RON and MON test. SI engines have evolved along the direction of the red arrow as a result of increasing desire for higher efficiency and power density over the past decades (Kalghatgi and Stone, 2017); (B) the average engine K-values have declined over the years with some modern engines already operating beyond RON conditions so that $\mathrm{K}$ is negative (CONCAWE, 2016). 
The model is a complex tool that seeks to maximize refinery profitability when meeting demands for refined petroleum products, by taking into account product prices and costs associated with feedstocks and utilities purchases (Pierru, 2007; Tehrani Nejad and Saitn-Antonin, 2014; Abdul-Manan et al., 2018). The optimization of the model is subjected to capacity constraints associated with each processing unit in the refinery, and it takes into consideration the fuels quality requirements specified within regulations. In this study, we combined the refineries in the Gulf Coast area to create a single, large and complex refining system to represent the region. The model was subsequently calibrated to meet the actual regional supply and demand balances in 2014 based on the products and feedstock prices. Our approach of aggregating refineries in a region may not necessarily represent the reality of the refining industry today as it ignores the cost of intermediate product transfers, and as a result it may lead to an over-optimized solution. The other alternative however, would be to model individual refineries, but this ignores the economic interactions between refineries, and the resulting feedback mechanisms, and so it may lead to an underoptimized outcome. The simplification that we have made greatly reduces the modeling efforts especially given the vast numbers of refineries in a region, and the calibration of the model partly mitigates the issues associated with over-optimization (MathPro, 2014). More discussions on our modeling approach can be found in Lu et al. (2016), Abdul-Manan et al. $(2017,2018)$ and Gordillo et al. (2017). Specifically the PADD III LP model utilized in this study has been used previously in other refinery assessments ( $\mathrm{Lu}$ et al., 2016; Abdul-Manan et al., 2018).

This study was performed under two different scenarios: (a) at fixed knock resistance, and (b) at higher knock resistance. The knock resistance of gasoline was specified using 3 different approaches: AKI, RON and OI assuming $K=-1$. In the first scenario, the knock resistance of gasoline was specified at 88, 93 and 103, for the AKI, RON and OI methods, respectively. We varied the concentration of ethanol in gasoline between 0 and $20 \%$ by volume. For the second scenario where the gasoline has higher knock resistance, we tested four different cases: (i) AKI
88 \& 10\% ethanol, (ii) AKI 88 \& 15\% ethanol, (iii) AKI 90 \& $10 \%$ ethanol, and (iv) AKI 90 \& 15\% ethanol. A summary of both scenarios and all test cases are provided in Figure 2.

Volumetric blending is the standard approach used in most refinery LP models, however it may not be appropriate for estimating the octane of ethanol blends (MathPro, 2014). Ethanol does not blend linearly with volume in gasoline (Figure 3A) for RON and MON. The RON gain as a result of ethanol addition is much steeper at lower concentrations (particularly below 40\% vol.), and for lower octane gasoline blendstock (Figure 3A). The linear by molar concentration method, though better than the volumetric approach, still has a tendency to underestimate the octane of the final ethanol-gasoline blends (Anderson et al., 2012b; Wang et al., 2017).

For the purpose of this study, we had to estimate the volumetric blending octane of ethanol for input into the LP model. Here, we adopted Anderson et al.'s non-linear molarbased correlation (Equation 1) (Anderson et al., 2012a), and the RON and MON of neat ethanol, to estimate the octane of the gasoline blendstock required in order to achieve the targeted octane of the final gasoline at a given ethanol concentration. The RON and MON of the neat ethanol were taken to be 109 and 90, respectively, based on (Anderson et al., 2012a; Foong et al., 2014). Anderson et al.'s correlation (Equation 1) includes a quadratic term to demonstrate the non-linearity of ethanol-gasoline blends, where $P$, in Equation (1), is $0.45-0.48$ for RON, and $0.94-1.21$ for MON. We took the midpoint value for $\mathrm{P}$ in our assessment $\left(P_{R O N}\right.$ $\left.=0.465, P_{M O N}=1.075\right) . \mathrm{ON}_{\mathrm{g}}, \mathrm{ON}_{\mathrm{b}}$, and $\mathrm{ON}_{\mathrm{e}}$ are the octane numbers of the finished gasoline, gasoline blendstock and neat ethanol, respectively, while $\mathrm{X}_{\mathrm{e}}$ is the molar percentage of ethanol in the final ethanol-gasoline blend.

$$
\begin{aligned}
O N_{g}= & \left(1-X_{e}\right) \times O N_{b}+X_{e} \times O N_{e} \\
& +P \times X_{e} \times\left(1-X_{e}\right) \times\left(O N_{e}-O N_{b}\right)
\end{aligned}
$$

Then, using the octane of the blendstock ( $\mathrm{BOB}$, blendstock for oxygenate blending), we estimated the equivalent volumetric

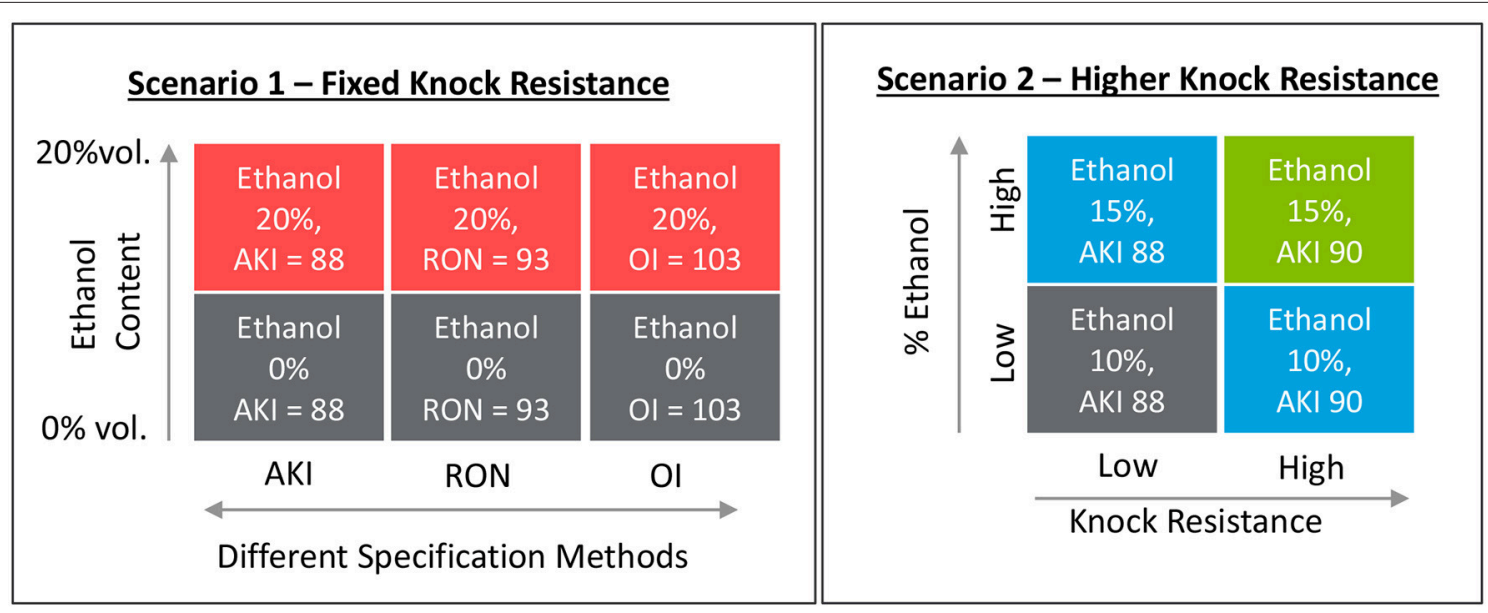

FIGURE 2 | Summary of scenarios 1 and 2 evaluated in this assessment. 

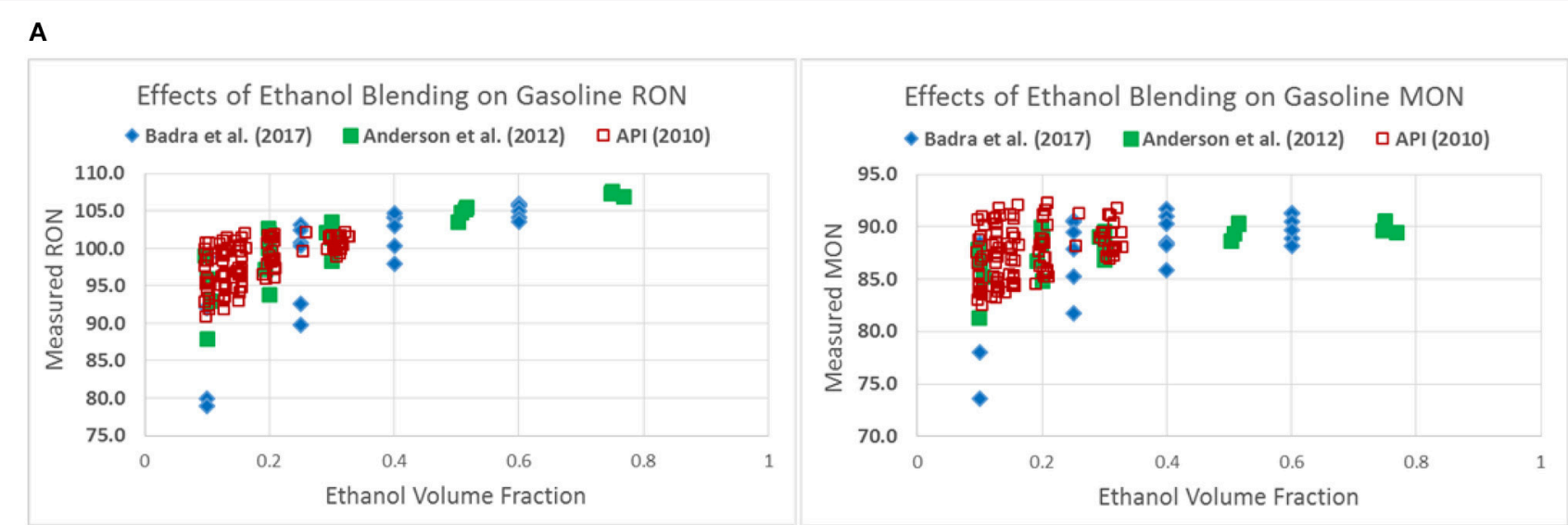

B
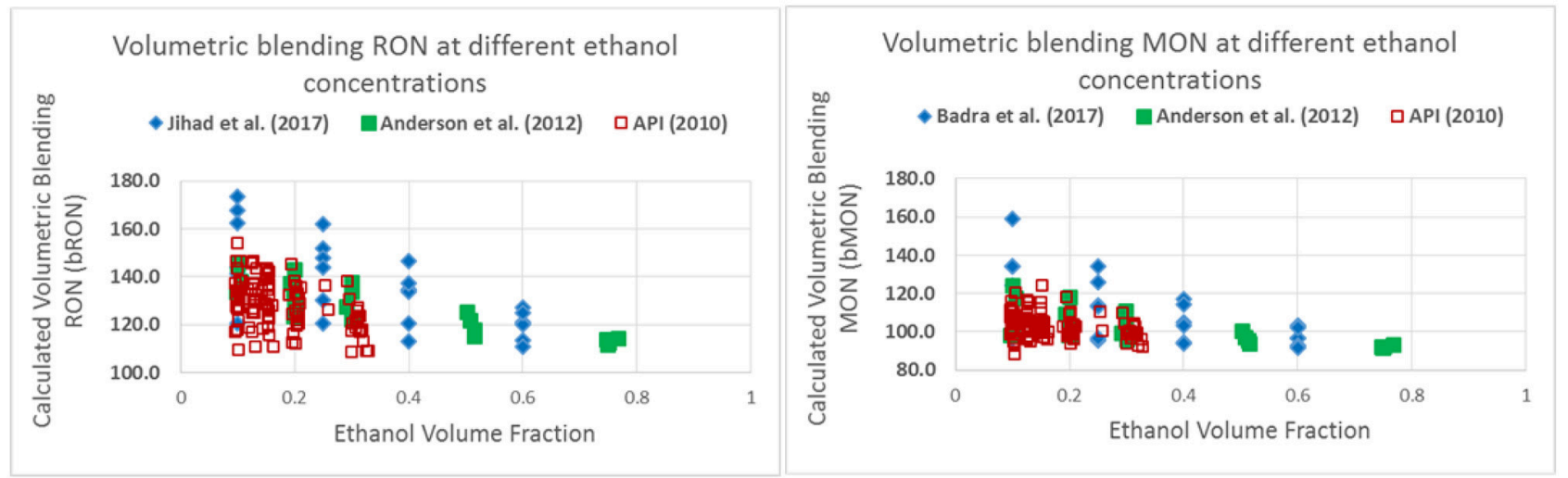

FIGURE 3 | Effects of ethanol-gasoline blend on the (A) measured RON and MON reported in the literature, and (B) the estimated volumetric blending RON and MON (bRON \& bMON) calculated in this study.

blending octane of ethanol $\left(\mathrm{ON}_{\mathrm{e}-\mathrm{vol}}\right)$ required using (Equation 2) for input into the model.

$$
O N_{g}=V_{e} \times O N_{e-v o l}+\left(1-V_{e}\right) \times O N_{b}
$$

An identical approach has also been used recently by Zhang and Sarathy (2016), in which for an E10 gasoline with RON 95 and MON 85, the volumetric blending octane for ethanol was estimated to be 145 and 114 for bRON (blending RON) and bMON (blending MON), respectively. By using this approach, we estimated that the volumetric blending octane of ethanol, for blends of $10-20 \%$ by volume, is between $152-156$ and $133-$ 137 for bRON and bMON, respectively, to achieve finished gasoline with a RON of about 93 . To reduce the computational efforts, we used the midpoint values of 155 and 135 for bRON and bMON, respectively. Although still within the ranges reported in recent literature (bRON: 109-174, bMON: 88159) (Table 2 and Figure 3B), we accept that these are slightly on the higher side. Therefore, we repeated the analyses using different combinations of blending RONs and MONs to assess the sensitivity of the outcomes to our modeling assumptions. The following bRON/bMON combinations were used in the sensitivity assessment: 145/125 and 140/110.

\section{RESULTS}

\section{Scenario 1: At Fixed Gasoline Knock Resistance}

Figure 4 shows the changes in gasoline composition as the concentration of ethanol is increased from 0 to $20 \%$ by volume for the AKI-based specification method, at fixed octane rating. As more ethanol is being used, other high octane refinery streams are displaced from the gasoline pool. The choice of which high octane streams to be displaced depends on the overall refinery economics, which include the availability and constraints of installed process unit capacities, demand for intermediate streams for blending into other refined products, the volume and price of the final fuels, and more. In our analysis, we found that reformates, FCC gasoline, alkylates and isomerates can be displaced by ethanol. Ethanol, in addition to its high octane rating, also has zero sulfur content, thus making it an excellent component for low sulfur gasoline. This leads to a lower demand for refinery hydrogen as less hydro-desulfurization is required (Figure 5). Given the increasingly stringent sulfur requirements in transport fuels specifications worldwide, ethanol can likely provide some relief to refineries especially those that are severely hydrogen constrained. 
TABLE 2 | Effects of ethanol blending on the measured RON and MON of gasolines at different concentrations and for different blendstocks reported in the literature.

\begin{tabular}{|c|c|c|c|c|c|c|}
\hline References & Ethanol content & RON of BOBs & MON of BOBs & Estimated bRON & Estimated bMON & Remarks \\
\hline Badra et al., 2017 & $10-60 \%$ & $69.5-96.4$ & $66.9-87.4$ & $111-174$ & $92-159$ & $\begin{array}{l}\text { Data were extracted for FACE } \\
\text { fuels only. }\end{array}$ \\
\hline Anderson et al., 2012a & $10-75 \%$ & $81.6-97.5$ & $76.6-88.0$ & $112-145$ & $92-124$ & \\
\hline \multirow[t]{2}{*}{ API, 2010} & $10-30 \%$ & $84.0-98.8$ & $80.3-91.3$ & $109-154$ & $88-124$ & $\begin{array}{l}\text { Gasolines sampled across the } \\
\text { US and splash-blended with } \\
\text { ethanol }\end{array}$ \\
\hline & \multicolumn{2}{|c|}{ Summary range } & & $109-174$ & $88-159$ & \\
\hline
\end{tabular}

The estimated volumetric blending RON (bRON) and MON (bMON) were calculated in this study.

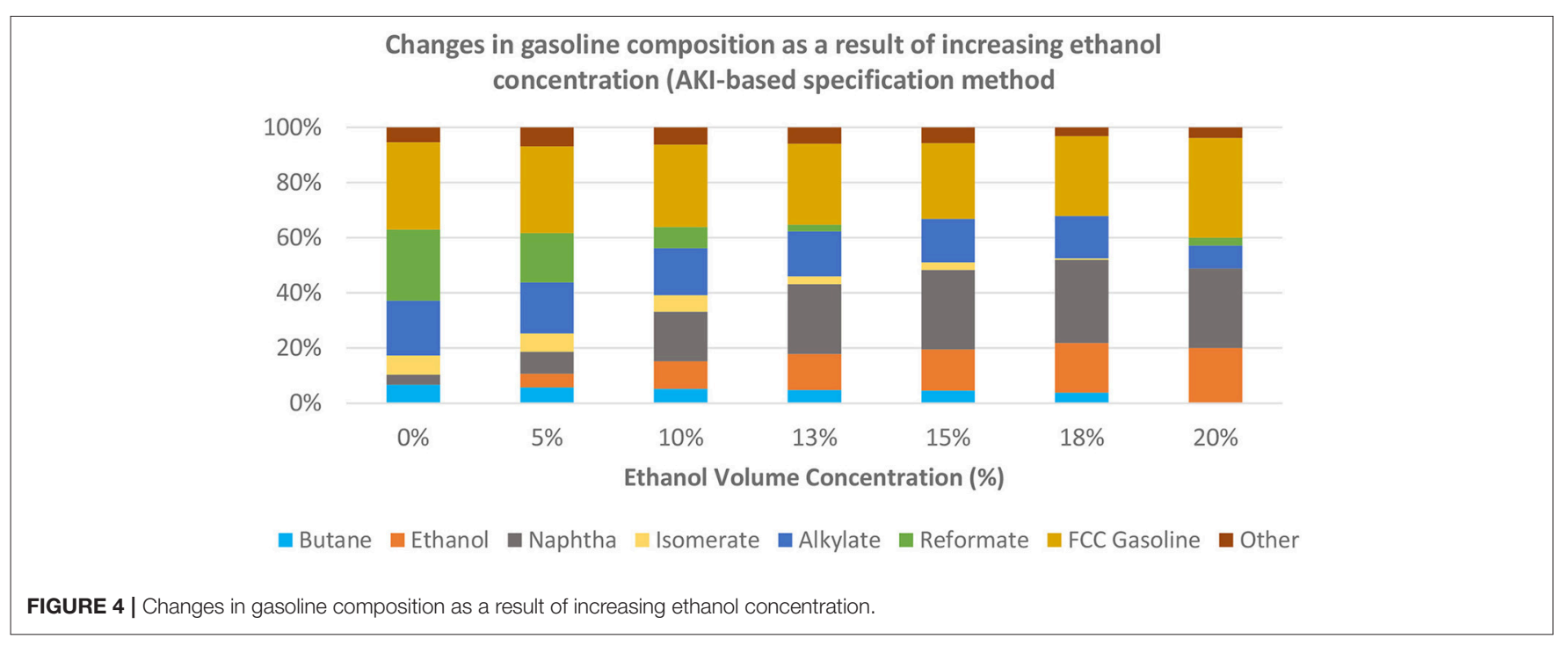

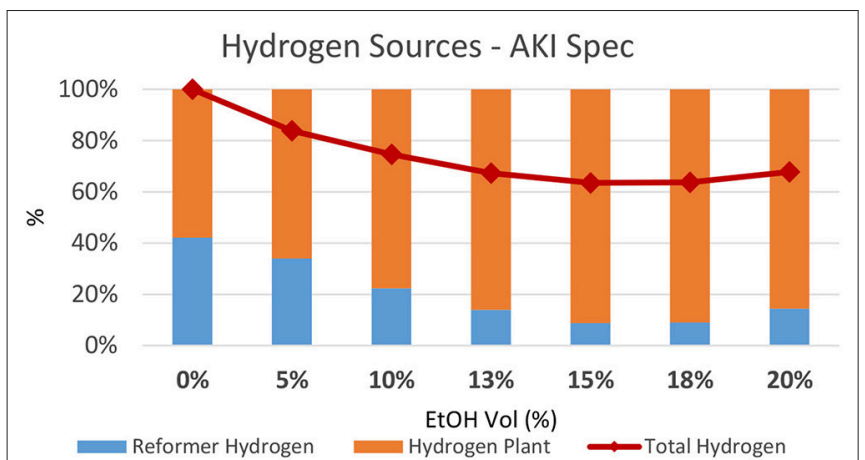

FIGURE 5 | Drop in reformer hydrogen with increasing use of low sulfur, high octane ethanol.

Typically, a refinery obtains hydrogen from a combination of (1) the hydrogen plant, which is an on-purpose hydrogen production facility through steam methane reforming of natural gas, and (2) the reformer, a high octane production unit with hydrogen as a by-product. Here we found that the lower overall demand for hydrogen, and the reduced need for producing higher octane component, resulted in large displacement of reformate in the final gasoline composition (Figure 4).
The displacement of reformate, a high octane refinery component, also allows for significantly more naphtha, a lower octane stream, to be blended into gasoline (Figure 4) while still meeting the octane specification. As a result, the sensitivity (i.e., $\mathrm{S}=\mathrm{RON}-\mathrm{MON}$ ) of the gasoline drops with increasing ethanol content (Figure 6). This is counter intuitive given that ethanol has very high sensitivity of close to 20 . The unintended consequence arises from the refinery's re-optimization strategy in response to increasing ethanol blending requirements, which enables naphtha, typically possessing very low sensitivity of about $1-2$, to be blended at much higher concentrations into gasoline. Interestingly, the drop in gasoline sensitivity with increasing ethanol content is more pronounced for the AKI and RON based specification methods than the alternative OI-based method (Figure 6). This is because, when gasoline knock resistance is specified by $\mathrm{OI}$ to meet the requirement of an engine with $K=$ -1 , implicitly we are moderating the increase in naphtha content of the final gasoline pool.

The knocking tendency of a gasoline fuel depends on the engine's operating conditions, and octane specifications have to meet evolving needs of the engines. Figure 7 plots the knock resistance of the fuel in terms of OI against ethanol concentration; refinery blending of the fuel is done assuming that $\mathrm{K}$ is +0.5 (Figure 7A), 0 (Figure 7B), and -1 (Figure 7C). In Figure 7 we show that the traditional RON or AKI specification 


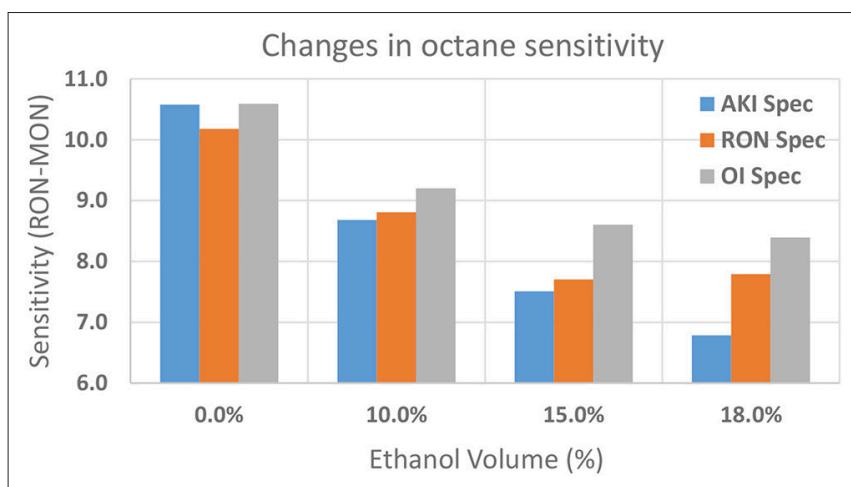

FIGURE 6 | Faster drop in gasoline sensitivity with traditional octane specification methods than in an octane index-based method.

methods are less reflective of the needs of more modern engines with increasingly negative $K$-values. An AKI specification method, effectively aims to satisfy the knocking resistance required by an engine with a $0.5 \mathrm{~K}$-value (Figure 7A), whereas the RON method is based on meeting the needs of a $K=0$ engine (Figure 7B). In both methods, more modern engines with negative $K$-values are likely to experience higher knocking tendency with increasing ethanol concentrations given that the sensitivity of the fuel drops due to higher naphtha contents in the re-optimized gasoline formulation. On the other hand, the OI-based specification method achieves the desirable knocking resistance by moderating the use of naphtha, but also at the same time the refinery compensates the drop in sensitivity by increasing the RON of the final gasoline (Figure 7C). And so, while the finished gasoline continues to be fit for a $K=-1$ engine, the blend reformulation also provides additional octane benefit to less modern engines $(K \geq 0)$ through higher RON, MON and AKI. This suggests that an OI based specification method not only ensures that the fuel continues to be fit for purpose for older and existing fleet in the market, but there may also be efficiency benefits to be gained.

Many fuels blending studies and engine tests previously conducted using ethanol containing gasolines were performed using fuel blends prepared by splash-blending ethanol into an existing market gasoline. Indeed, this is the practical approach that many commercial refiners used to take in the past when the volumes of ethanol-containing fuels were still small (Anderson et al., 2012a). This resulted in octane "give-away" in some of the gasoline fuels containing ethanol. However, with increasing demand for ethanol-gasoline blends, this is no longer a costeffective method and so refineries have had to adapt by producing a special gasoline blendstock ( $\mathrm{BOB})$, with lower octane rating, specifically for blending with ethanol. This involves a reoptimization of refinery operation to take into account of increased ethanol availability to a refiner, for use as a high octane blending component. Reportedly this took place in the U.S. by 1990 (Anderson et al., 2012a). Figure 8 depicts the historical evolution of octane in the U.S. since the 1980s, where it can be seen that there is an apparent drop in octane index (at $K=$ -1 ) for E10 gasoline post 1990. Conversely, there is no evidence
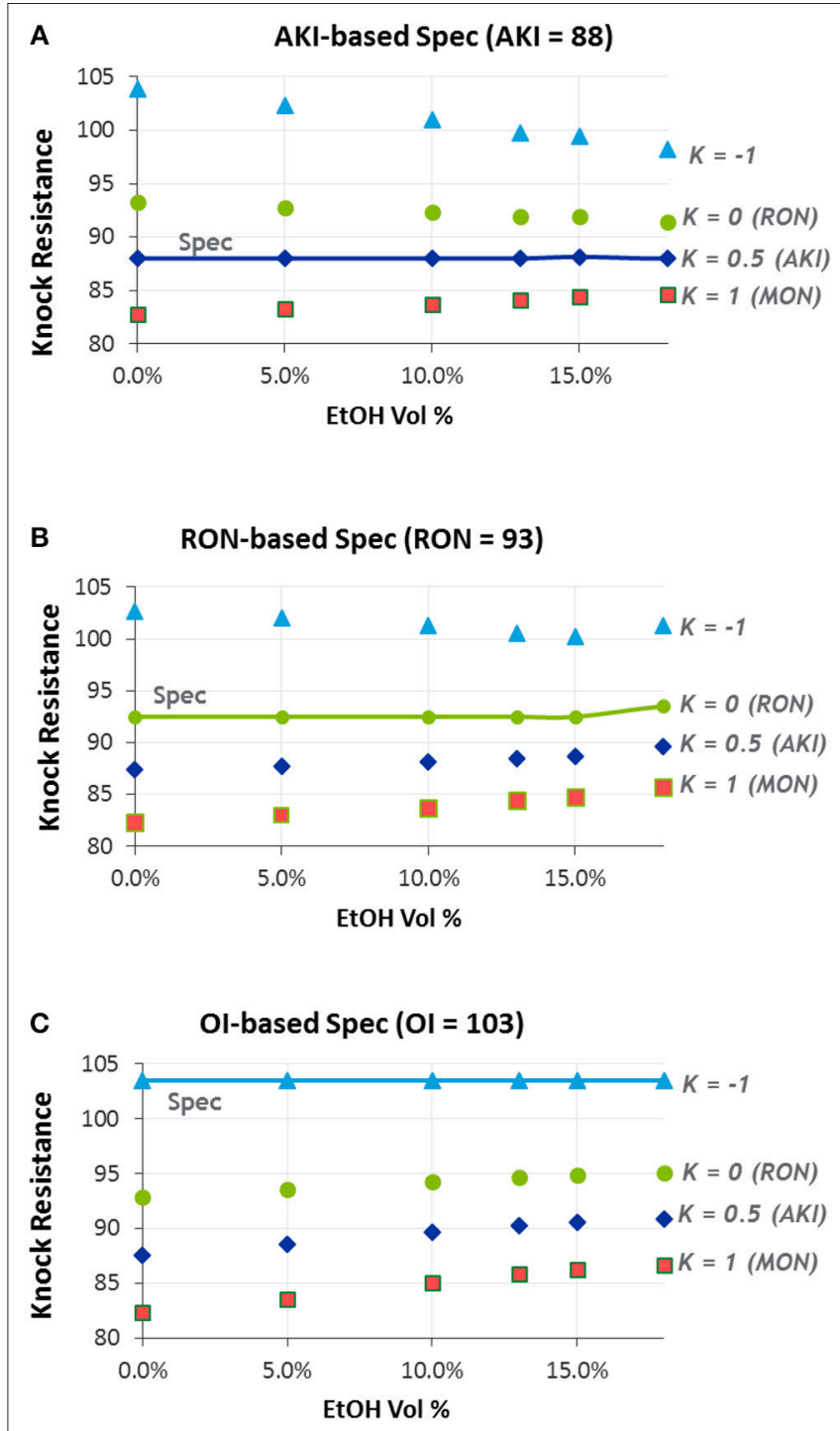

FIGURE 7 | Knock resistance of gasoline produced via 3 different specification methods, at varying ethanol concentrations, under different engine $\mathrm{K}$ parameters. Refinery blending of the fuel is done assuming that $K$ is $(\mathbf{A})+0.5$, (B) 0 , and (C) -1 .

of similar changes in the octane index of gasoline that did not contain ethanol (E0) (Figure 8A). This drop in octane index for E10 gasoline in the U.S. can be attributable to the adaption of refineries to increasing use of ethanol. While the sensitivity of the E10 gasoline also dropped during this period, it is unclear how the composition of gasoline had changed over the years. Since the RON of the gasoline had simultaneously decreased (Figure 8B), and the fact that lower RON components also tend to have lower sensitivity, it is thus not possible to directly attribute the apparent drop in sensitivity to higher naphtha contents of the finished gasoline.

As far as we are aware, the indirect effects of ethanol blending on gasoline sensitivity has not been reported before. It is not clear if this is an artifact of our modeling assumptions, particularly 
A

Knock Resistance of U.S. Gasoline

- E0 - E10

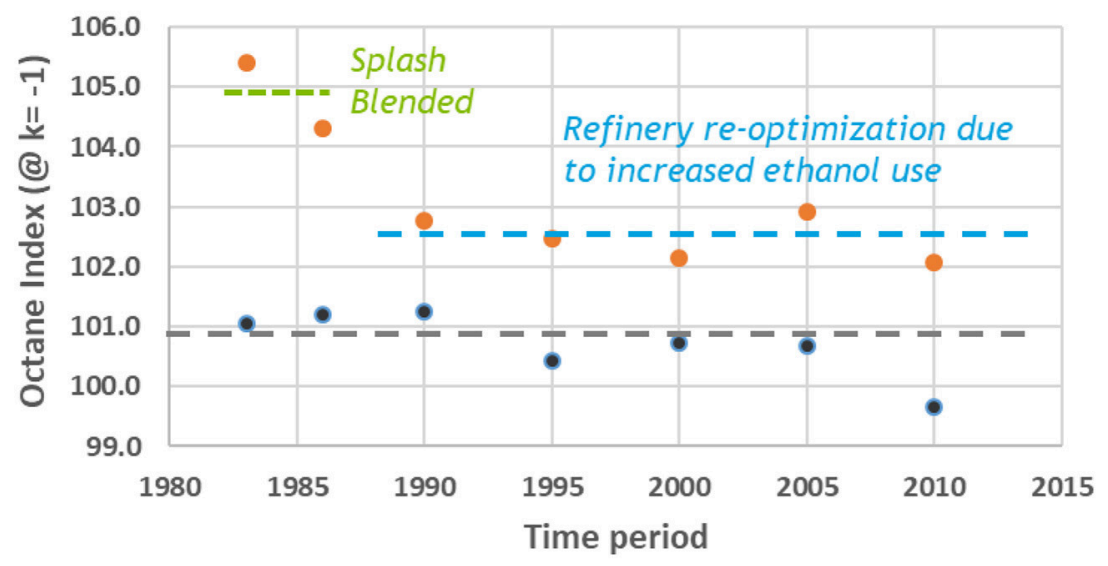

B Historical RON \& Sensitivity of E10 in the US

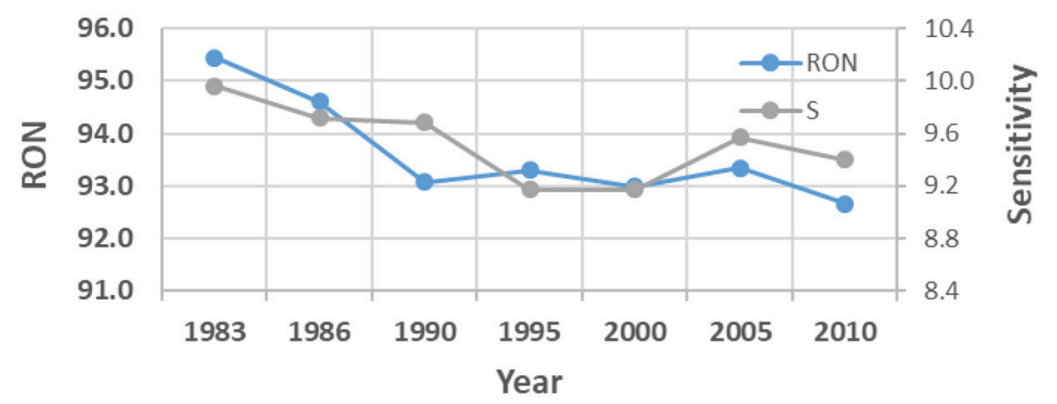

FIGURE 8 | Historical octane data in the U.S. showing (A) evolution in octane index, and (B) changes in RON and sensitivity over time. Refinery re-optimization became more widespread post 1990 (Anderson et al., 2012a).

the blending RON and MON adopted for ethanol in this study. As mentioned in the methodology section, there is a large uncertainty associated with the volumetric blending octane of ethanol. And so we repeated the analysis using different sets of bRON and bMON values (Figure 9) to assess the sensitivity of our findings to the modeling assumptions. Three ethanol bRON/bMON combinations were assessed, those are: 155/135 (base case), 145/125 and 140/110, which correspond to blending sensitivities of 20,20, and 30, respectively.

Figure 9 shows the effects of adopting different combinations of blending RONs and MONs for ethanol on the sensitivity (Figure 9A) and octane index $(K=-1)$ (Figure 9B) of finished gasoline using the RON and OI based specification methods. The blending RON and MON adopted for ethanol can have a large impact on the octane sensitivity of the re-optimized gasoline formulation (Figure 9A). And, in particular, a larger ethanol blending sensitivity leads to a lower drop in octane sensitivity of the finished gasoline. Neat ethanol has a sensitivity of about 20 (Anderson et al., 2012a; Foong et al., 2014) and here we have presented the results of utilizing blending sensitivity values of between 20 and 30; this is based on Anderson et al. (2012a) for gasoline blendstock with RON of between 80 and 90, and for blending with ethanol up to $30 \%$ by volume (Figure 10).
Although both specification methods, RON and OI, showed a drop in octane sensitivity for the finished gasoline when larger blending sensitivity value is adopted for ethanol, the OI-based method produced a slightly smaller drop. However, more to the point, the OI-based method does not compromise the enginerequired knock-resistance of the final gasoline, regardless of this drop in sensitivity (Figure 9B). As discussed in preceding paragraphs, the OI-based method does this by raising the RON of the final gasoline to compensate for the drop in sensitivity. Given the high uncertainty in the ethanol blending octane values, which can fluctuate based on the octane of the gasoline blendstock and its chemical composition, the OI-based specification method provides certainty that the minimum gasoline knock-resistance required by the engine will be met, one way or the other. This certainty will also be particularly useful especially to minimize variability between refineries who may adopt different blending properties for ethanol.

\section{Scenario 2: At Higher Gasoline Knock Resistance}

Figure 11 shows the impacts of specifying higher gasoline octane, with and without ethanol, on the effective octane index of gasoline under three different specification methods. The effects 


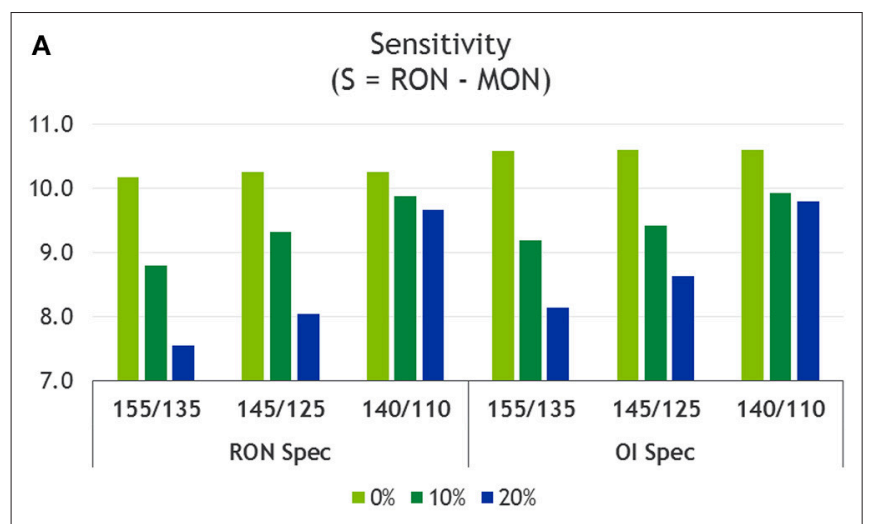

B $\quad \begin{gathered}\text { Octane Index } \\ (\mathrm{OI}=\mathrm{RON}-\mathrm{kS} ; \text { @ } \mathrm{K}=-1)\end{gathered}$

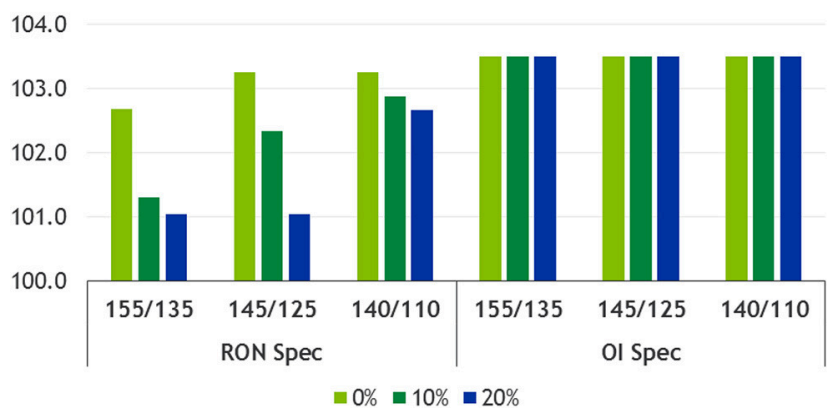

FIGURE 9 | Effects of ethanol blending RON (bRON) and MON (bMON) assumptions on (A) octane sensitivity, and (B) octane index of finished gasoline at $0 \%, 10 \%$ and $20 \%$ ethanol contents. The $3 \mathrm{bRON} / \mathrm{bMON}$ combinations were 155/135, 145/125, and 140/110, with blending sensitivities of 20,20 , and 30 , respectively.

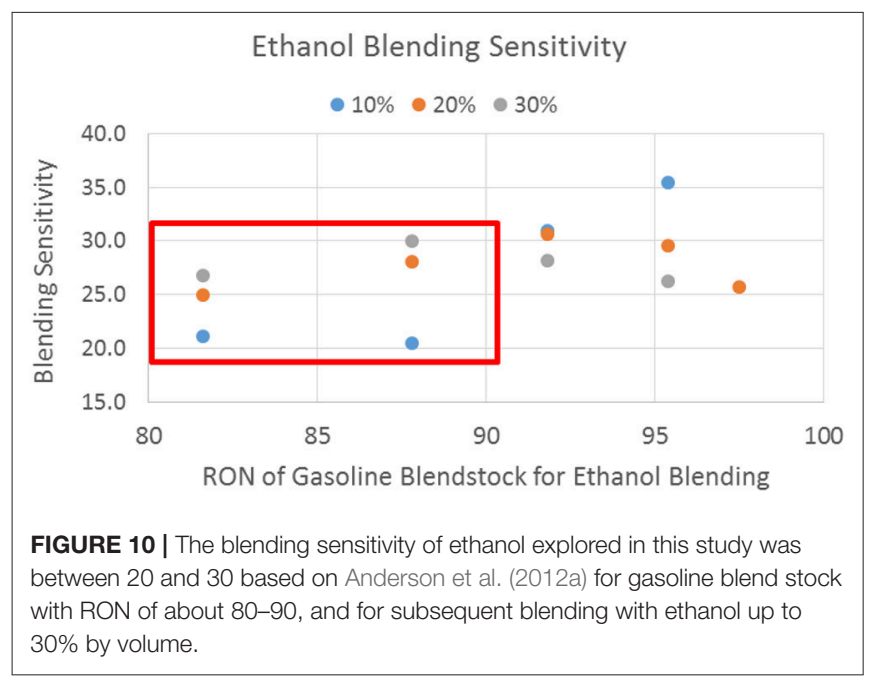

of ethanol addition on the octane index of gasoline are similar to the observations made earlier in the preceding section, regardless of the octane level targeted for gasoline production. However, it is interesting to note that the OI-based method is uncompromising on the targeted gasoline knock resistance, whereas the more traditional methods may compromise the effective knock resistance for negative $\mathrm{K}$ engines.

However, it is important to stress that the OI method is not exclusive for engines with negative $K$-values. The OI specification method can also be used to specify the knocking resistance required for non-negative $\mathrm{K}$ engines. We envision that several gasoline grades can be offered at the retail stations, which is already the case today. The gasoline grades may be differentiated to satisfy different engine $\mathrm{K}$ constants as defined within the car's operating manual. The OI specification method aims to improve fuel-engine matching by integrating engine requirements into gasoline manufacturing. It does so by internalizing the relative importance of RON and MON for different engine characteristics.

\section{Impacts on Efficiency of SI Engines}

A key driving force behind the desire for more octane is the fact that it can enable improved efficiency in future SI engines. And so in this section we provide a rough estimation of the impacts of changing specification method on the efficiency of SI engines. We performed this by using the recommended correlations (Table 3) that were recently reported by Leone et al. in a review paper that had summarized the effects of fuel octane rating, compression ratio, and ethanol content on the efficiency of SI engines (Leone et al., 2015).

Figure 12 depicts the changes in gasoline knock resistance, measured by octane index with $K=-1$, simply by switching from an AKI based specification to an equivalent specification based on OI for a gasoline containing $10 \%$ ethanol by volume. As demonstrated in previous sections, the improvement in knock resistance is due to the higher RON gasoline produced under an OI-based method as a means to compensate for the drop in sensitivity attributable to the refinery's re-optimization strategy. It has been estimated that this increase in gasoline RON can roughly lead to about $1.5 \%$ efficiency gain in a turbocharged SI engine enabled by a higher compression ratio.

\section{DISCUSSION}

Modern gasoline engines continue to be pushed to meet ever greater fuel efficiency standards, lower emissions requirements and increased performance levels. Engine designers have responded by pursuing multiple promising technologies in parallel to enhance the fuel economy of their engines, and increasingly they are limited by the onset of knock. At the knock-limited operating conditions, the engines often display negative $\mathrm{K}$ characteristics. As we continue to push the boundaries of an efficient SI engine, increasingly it means that there is a diminishing role for MON with a progressively greater emphasis placed on RON for meeting the higher octane requirements of the engine (Figure 13). Practically, what this means is that, for a given RON, fuels with a lower MON is preferable. However, octane specifications that continue to place equal emphasis on RON and MON, such as the U.S.'s AKI or the EU's RON and MON methods, can be considered outdated particularly as we strive to enable new generations of efficient SI engines (Figure 13). 


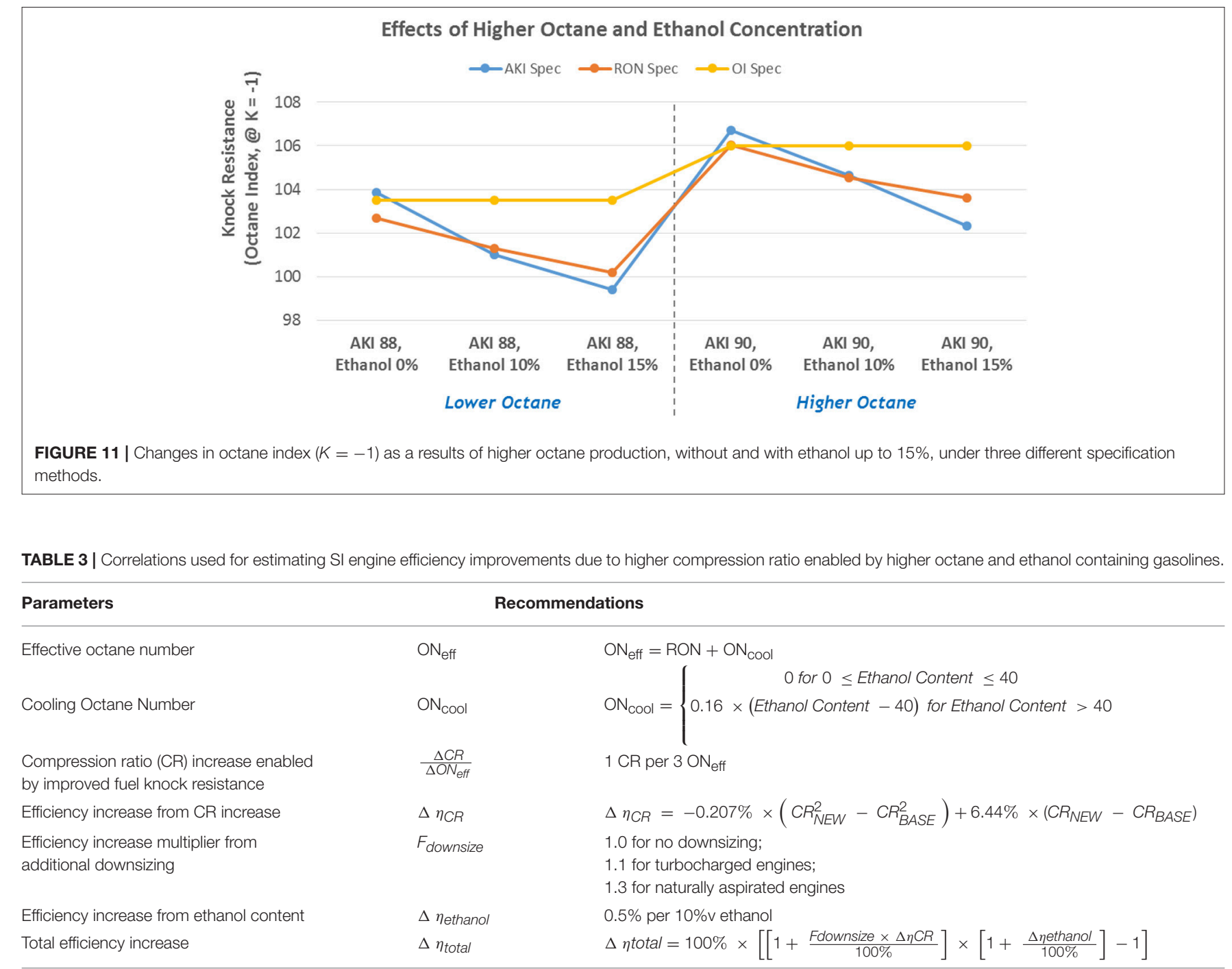

Recommended parameters taken from Table 1 in Leone et al. (2015).

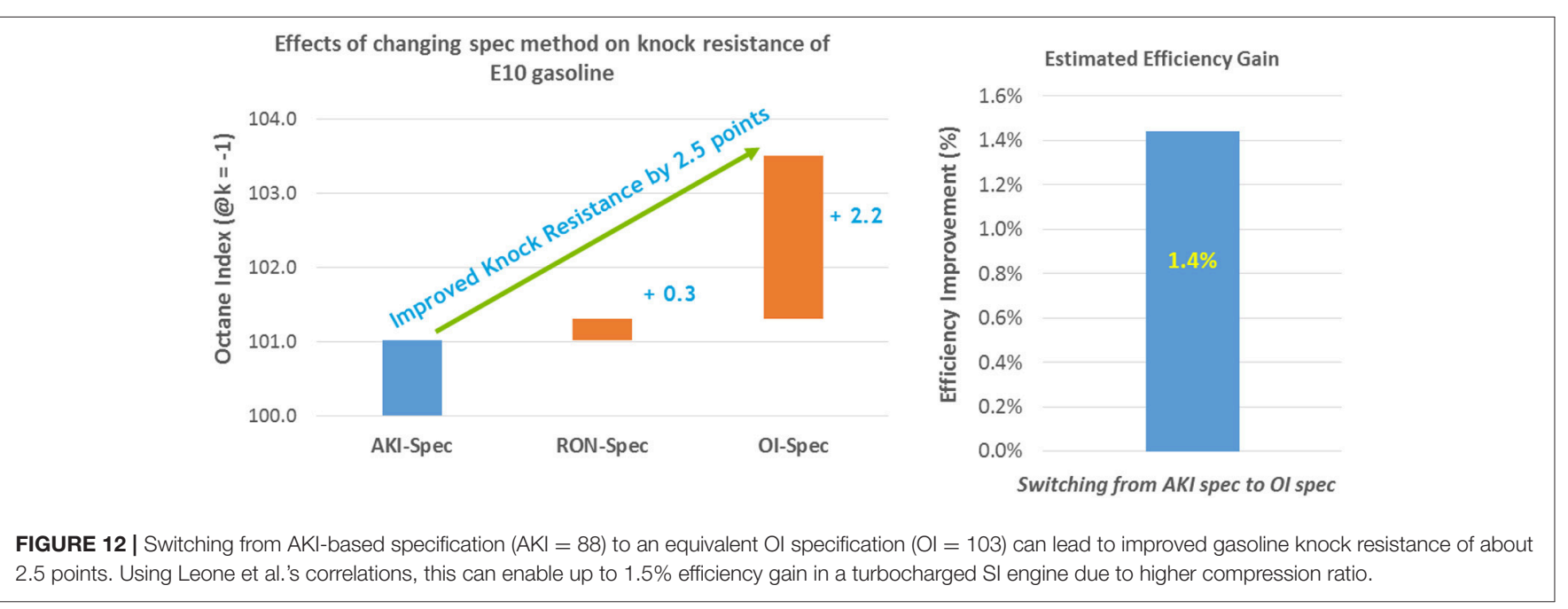




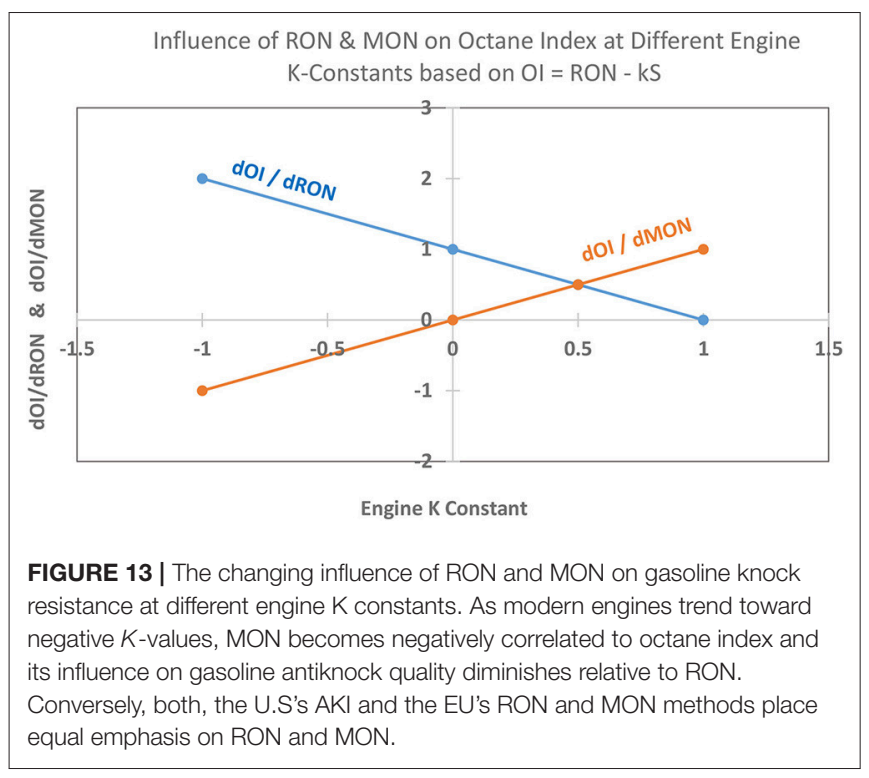

The use of high octane ethanol in gasoline offers significant opportunities to improve the efficiency of SI engines. But our analysis suggests that because of the way octane is being specified worldwide, the ethanol blending strategies adopted by refineries today may result in a drop in gasoline octane sensitivity due to the higher use of naphtha in the reformulated gasoline. For modern gasoline engines with negative $\mathrm{K}$ characteristics, this can compromise the knock-resistance of the gasoline with increasing ethanol contents. However, this can be mitigated in three different ways.

The first approach is to splash-blend ethanol in finished gasoline, and not reformulate a new gasoline blendstock for ethanol blending. Splash-blending was in fact the standard practice when the volume of ethanol was still low and refineries would "give-away" octane. Ethanol splash-blending allows for the high octane and high sensitivity of the ethanol to be better exploited especially in an engine that favors gasoline with high RON and low MON. However, with growing volumes for ethanol blends, many refiners may not consider this as an economically feasible solution.

The other possible approach involves increasing the minimum RON specification of the finished gasoline. By doing so, we are meeting the octane requirements of the engine through higher RON as a means to compensate for the drop in sensitivity with increasing ethanol contents. However, given the way octane is specified today, which implicitly pushes for a minimum MON (Figure 14B), there is a risk that MON might also go up with increasing RON, so effectively we are pushing gasoline into a less preferable direction. Consider for example, a fuel that has a RON of 92 and MON of 81, and thus an OI of 103 (at $K=$ -1 ). If RON is increased to 94 , the maximum MON the fuel is permitted to have is 85 , above which its OI will drop below 103 . This suggests the need for a maximum MON specification, as opposed to the approach taken in many existing fuel standards today that specify a minimum MON. A specification that imposes a maximum MON can prevent unwanted drop in

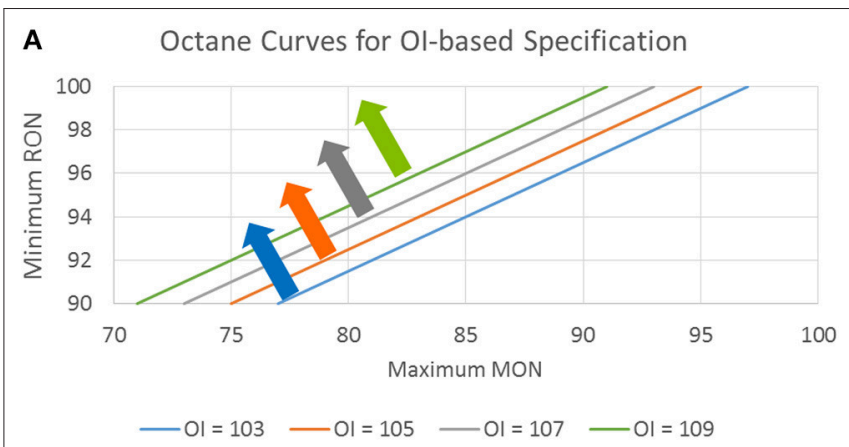

B Octane Curves for AKI-based Specification

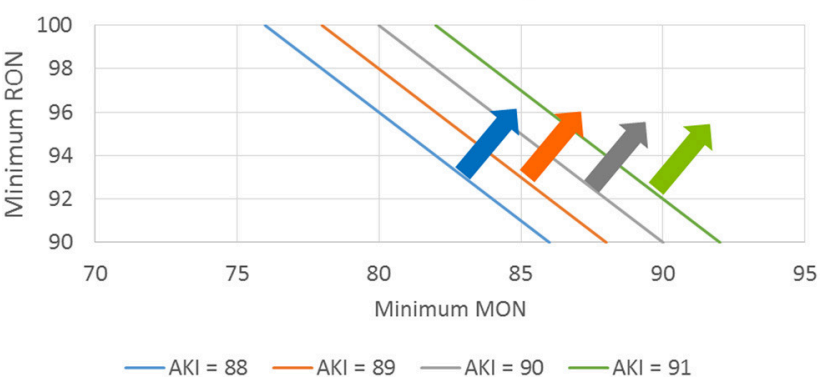

FIGURE 14 | The octane curves define the RON and MON required to meet different gasoline antiknock qualities under (A) OI-based and, (B) AKI-based specification methods. An AKI standard pushes gasoline antiknock quality into a different direction compared to engine trends.

the knock-resistance of the gasoline, particularly under knocklimited operating conditions of a modern SI engine. However, a maximum MON specification effectively mimics an OI based method through a more prescriptive stipulation of the minimum RON and maximum MON required, and therefore the approach reduces a refinery's flexibility. Moreover, the maximum MON approach only caters for modern engines (with negative $K$ values) that require fuels with high RON and low MON. Thus, it may not be appropriate for some existing fleet in the market that may still benefit from having a higher MON gasoline.

An alternative approach would be to adopt a new specification method based on OI (at $K=-1$ ). The OI-based method ensures that the anti-knock quality of the fuel is being met either through higher RON and/or higher sensitivity (Figure 14A), and thus offers more flexibility to refiners. An OI-based specification method internalizes the diminished role that MON plays in the overall anti-knock quality of gasoline in modern SI engines. Our initial analysis also suggest that there is a potential engine efficiency benefit of around $1.5 \%$ to be gained simply by switching from an AKI-based specification method to an equivalent octane specification based on OI. Equally important, as we have shown in Figure 7C, an OI based method not only ensures that the antiknock quality of the fuel is fit for a modern SI engine (with negative $K$-value), but there is also a potential efficiency benefit that can be gained by older fleets (with positive $K$ values) from the higher RON, MON and AKI of the reformulated gasoline. 
Like any other modeling exercise the strength of our analysis depends on the assumptions that were made. One of the biggest uncertainties include the blending octane values that were adopted for ethanol. This has been discussed in detail as part of the sensitivity analysis performed in section Scenario 1: At Fixed Gasoline Knock Resistance. But equally important is the fact that this uncertainty is not limited to the research community and may present itself as a practical challenge to many analysts and refiners. A more pragmatic approach for dealing with the blending octane values for ethanol has to be developed especially as ethanol-gasoline blends become more widespread, or ethanol is used at higher concentrations in gasoline.

In addition, our modeling technique involves combining refineries in the U.S. PADD III to create a single, large and complex refinery to represent the region. This is the approach that has been adopted by CONCAWE to support many previous EU refining studies (CONCAWE, 2006, 2009, 2017). Moreover, Argonne National Laboratory, in their 2015 report on highoctane fuels also recommended the use of aggregated refinery models to represent the U.S. PADD regions as the next steps to complement their methodological approach (Han et al., 2015). However, further analysis using a variety of methodological approach would permit better informed decisions regarding the appropriateness of different gasoline octane specification methods and their impacts on gasoline anti-knock quality as means to enable improved SI efficiencies.

\section{CONCLUSIONS}

The findings of this study has several important implications.

The growing use of ethanol to satisfy the rising appetite for knock-resistant fuel in efficient and modern SI engines can lead

\section{REFERENCES}

Abdul-Manan, A., Bakor, R., and Zubail, A. (2018). Analyzing the effects of Gasto-Liquid (GTL) diesel blending on the efficiency and emissions of petroleum refineries and transport fuels in the U.S. and Europe. Transport. Res. D 59, 259-267. doi: 10.1016/j.trd.2018.01.010

Abdul-Manan, A. F., Arfaj, A., and Babiker, H. (2017). Oil refining in a $\mathrm{CO}_{2}$ constrained world: effects of carbon pricing on refineries globally. Energy 121, 264-275. doi: 10.1016/j.energy.2017.01.046

Anderson, J., DiCicco, D., Ginder, J., Kramer, U., Leone, T., RaneyPablo, H., et al. (2012a). High octane number ethanol-gasoline blends: quantifying the potential benefits in the United States. Fuel 97, 585-594. doi: 10.1016/j.fuel.2012.03.017

Anderson, J., Leone, T., Shelby, M., Wallington, T., Bizub, J., Foster, M., et al. (2012b). "Octane numbers of ethanol-gasoline blends: measurements and novel estimation method from molar composition," in SAE Technical Paper 2012-011274. doi: 10.4271/2012-01-1274

API (2010). Determination of the Potential Property Ranges of MidLevel Ethanol Blends. Final Report, American Petroleum Institute, Washington, DC.

Badra, J., Alramadan, A., and Sarathy, S. M. (2017). Optimization of the octane response of gasoline/ethanol blends. Appl. Energy 203, 778-793. doi: 10.1016/j.apenergy.2017.06.084

BP (2014). BP Energy Outlook 2035. London: BP. to a counterintuitive drop in octane sensitivity due to the way a refinery re-optimizes the gasoline blendstock formulation. This happens because gasoline anti-knock specifications continue to place equal importance on RON and MON.

For engines that operate beyond the RON operating conditions, such that the engine $\mathrm{K}$ constant is negative, MON has a declining and negative influence on gasoline anti-knock quality. What this means is that, at a given RON, fuel with a lower MON has a higher knock resistance. This has been repeatedly demonstrated to be the case for many modern and efficient SI engines. As such, specifications that continue to exert pressure on both, RON and MON, are effectively pushing fuels toward a different direction compared to engine development trends.

This study is a first attempt to explore the use of octane index as an alternative means for specifying gasoline knockresistance from a refining perspective. The OI approach appears to offer advantages over other traditional specification methods and thus it is recommended that the approach is investigated further.

\section{AUTHOR CONTRIBUTIONS}

All authors listed have made a substantial, direct and intellectual contribution to the work, and approved it for publication.

\section{ACKNOWLEDGMENTS}

We gratefully acknowledge Victor Gordillo Zavaleta for his suggestions on refinery LP model building without implicating him in any way. The authors are solely responsible for the contents of this paper.

Chang, J., Viollet, Y., Alzubail, A., Abdul-Manan, A. F. N., and Al Arfaj, A. (2015). "Octane-on-demand as an enabler for highly efficient spark ignition engines and greenhouse gas emissions improvement," in SAE Technical Paper 2015-01-1264. doi: 10.4271/2015-01-1264

CONCAWE (2006). Techno-Economic Analysis of the Impact of the Reduction of Sulphur Content of Residual Marine Fuels in Europe. Report no. 2/06, CONCAWE, Brussels.

CONCAWE (2009). Impact of Marine Fuels Quality Legislation on EU Refineries at the 2020 Horizon. Report no. 3/09, CONCAWE, Brussels.

CONCAWE (2016). Phase 1: Effect of Fuel Octane on the Performance of Two Euro 4 Gasoline Passenger Cars. Brussels: CONCAWE.

CONCAWE (2017). Estimating the Marginal $\mathrm{CO}_{2}$ Intensities of EU Refinery Products. Report no. 1/17, CONCAWE, Brussels.

CRC (2017). Effects of Octane Number, Sensitivity, Ethanol Content, and Engine Compression Ratio on GTDI Engine Efficiency, Fuel Economy, and $\mathrm{CO}_{2}$ Emissions. Final report. CRC Report No. AVFL-20, Coordinating Research Council, Inc., Alpharetta, GA.

CRC Octane Group (2011). Fuel Antiknock Quality - Engine Response to RON versus MON - Scoping Tests. CRC Report No. 660, Coordinating Research Council, Alpharetta, GA.

EPA (2014). Light-Duty Automotive Technology, Carbon dioxide Emissions, and Fuel Economy Trends: 1975 Through 2014. U.S. EPA.

ExxonMobil (2015). The Outlook for Energy: A view to 2040. Texas, TX: ExxonMobil. 
Foong, T. M., Morganti, K., Brear, M., da Silva, G., Yang, Y., and Dryer, F. (2014). The octane numbers of ethanol blended with gasoline and its surrogates. Fuel 115, 727-739. doi: 10.1016/j.fuel.2013.07.105

Gordillo, V., Rankovic, N., and Abdul-Manan, A. F. (2017). Customizing $\mathrm{CO}_{2}$ allocation using a new non-iterative method to reflect operational constraints in complex EU refineries. Int. J. Life Cycle Assess. 23, 1-15. doi: $10.1007 /$ s11367-017-1380-1

Gudde, N. J. (2017). Adaptation of oil refineries to make modern fuels. Proc. Institut. Mech. Eng. D Automob. Eng. J. 232, 1-17. doi: 10.1177/0954407016680522

Han, J., Elgowainy, A., and Wang, M. (2015). Well-to-Wheels Greenhouse Gas Emissions Analysis of High-Octane Fuels with Various Market Shares and Ethanol Blending Levels. Chicago, IL: Argonne National Laboratory.

Horning, H. (1923). "Effect of compression on detonation and its control," in SAE Technical Paper 230033. SAE International. doi: 10.4271/230033

IEA (2017). World Energy Outlook. Paris: International Energy Agency (IEA).

Kalamaras, C., Shaik, K., Kalghatgi, G., Babiker, H., Alsamah, A., McLeary, D., et al. (2017). SuperButol ${ }^{\mathrm{TM}}$ - A novel high-octane gasoline blending component. Fuel 195, 165-173. doi: 10.1016/j.fuel.2017.01.062

Kalghatgi, G. (2001). "Fuel anti-knock quality - part I. engine studies," in SAE Technical Paper 2001-01-3584. doi: 10.4271/2001-01-3584

Kalghatgi, G. (2014). Fuel/Engine Interactions. Warrendale: SAE International.

Kalghatgi, G., Head, R., Chang, J., Viollet, Y., Babiker, H., and Amer, A. (2014). An alternative method based on toluene/n-heptane surrogate fuels for rating the anti-knock quality of practical gasolines. SAE Int. Fuels J. Lubr. 7, 663-672. doi: 10.4271/2014-01-2609

Kalghatgi, G., and Johansson, B. (2018). Gasoline compression ignition (GCI) approach to efficient, clean and affordable future engines. Proc. Institut. Mech. Eng. D J. Automobile Eng. 232, 118-138. doi: 10.1177/0954407017694275

Kalghatgi, G., and Stone, R. (2017). Fuel requirements of spark ignition engines. Proc. Institut. Mech. Eng. D J. Automobile Eng. 232, 22-35. doi: 10.1177/0954407016684741

Leone, T. G., Anderson, J. E., Davis, R. S., Iqbal, A., Reese, R. A., Shelby, M. H., et al. (2015). The effect of compression ratio, fuel octane rating, and ethanol content on spark-ignition engine efficiency. Environ. Sci. Technol. 49, 10778-10789. doi: 10.1021/acs.est.5b01420

Liu, H., Wang, Z., and Wang, J. (2014). Methanol-gasoline DFSI (dual-fuel spark ignition) combustion with dual-injection for engine knock suppression. Energy 73, 686-693. doi: 10.1016/j.energy.2014.06.072

Lu, Z., Han, J., Wang, M., Cai, H., Sun, P., Dieffenthaler, D., et al. (2016). Well-towheels analysis of the greenhouse gas emissions and energy use of vehicles with gasoline compression ignition engines on low octane gasoline-like fuel. SAE Int. J. Fuels Lubr. 9, 527-545. doi: 10.4271/2016-01-2208

MathPro (2014). "Refining economics of U.S. gasoline: octane Ratings And Ethanol Content," in Supporting Information Document for Submission to Environmental Science and Technology (West Bethesda, MD: MathPro).

Mittal, V., and Heywood, J. (2010). The shift in relevance of fuel RON and MON to knock onset in modern si engines over the last 70 years. SAE Int. J. Engines 2, 1-10. doi: 10.4271/2009-01-2622
Morganti, K., Al-Abdullah, M., Alzubail, A., Kalghatgi, G., Viollet, Y., Head, R., et al. (2017). Synergistic engine-fuel technologies for light-duty vehicles: fuel economy and Greenhouse Gas Emissions. Appl. Energy 208, 1538-1561. doi: 10.1016/j.apenergy.2017.08.213

Partridge, R. D., Weissman, W., Ueda, T., Iwashita, Y., Johnson, P., and Kellogg, G. (2014). Onboard gasoline separation for improved vehicle efficiency. SAE Int. J. Fuels Lubr. 7, 366-378. doi: 10.4271/2014-0 1-1200

Pierru, A. (2007). Economics and the refinery's $\mathrm{CO}_{2}$ emissions allocation problem. Oil Gas Sci. Technol. Rev. IFP 62, 647-652. doi: 10.2516/ogst:2007034

Prakash, A., Cracknell, R., Natarajan, V., Doyle, D., Jones, A., Jo, Y., et al. (2016). Understanding the octane appetite of modern vehicles. SAE Int. J. Fuels Lubr. 9, 345-357. doi: 10.4271/2016-01-0834

Shaik, K., Xu, W., Abba, I., Mohammad, T., Shethna, H., and Mohammed, K. (2015). Process for Production of Mixed Butanols and Diisobutenes as Fuel Blending Components. Patent US2015/0225320A1.

Splitter, D., Pawlowski, A., and Wagner, R. (2016). A historical analysis of the coevolution of gasoline octane number and spark-ignition engines. Front. Mech. Eng. 1, 1-22. doi: 10.3389/fmech.2015.00016

Stradling, R., Williams, J., Hamje, H., and Rickeard, D. (2016). Effect of octane on performance, energy consumption and emissions of two Euro 4 passenger cars. Transport. Res.Procedia 14, 3159-3168. doi: 10.1016/j.trpro.2016. 05.256

Tehrani Nejad, M., and Saitn-Antonin, V. (2014). Factors driving refinery CO2 intensity, with allocation into products: comment. Int. J. Life Cycle Assess. 19, 24-28. doi: 10.1007/s11367-013-0634-9

Wang, C., Zeraati-Rezaei, S., Xiang, L., and Xu, H. (2017). "Ethanol blends in spark ignition engines: RON, octane-added value, cooling effect, compression ratio, and potential efficiency gain. Appl. Energy 191, 603-619. doi: 10.1016/j.apenergy.2017.01.081

Xu, W., and Vogel, S. (2011). Combustible Mixed Butanol Fuels. Patent US2011/0023355 A1.

Young, G., and Holloway, J. (1924). "Control of detonation," in SAE Technical Paper 240001 (SAE International). doi: 10.4271/240001

Zhang, B., and Sarathy, M. (2016). Lifecycle optimized ethanolgasoline blends for turbocharged engines. Appl. Energy 181, 38-53. doi: 10.1016/j.apenergy.2016.08.052

Conflict of Interest Statement: The authors declare that the research was conducted in the absence of any commercial or financial relationships that could be construed as a potential conflict of interest.

Copyright (c) 2018 Abdul-Manan, Kalghatgi and Babiker. This is an open-access article distributed under the terms of the Creative Commons Attribution License (CC $B Y)$. The use, distribution or reproduction in other forums is permitted, provided the original author(s) and the copyright owner(s) are credited and that the original publication in this journal is cited, in accordance with accepted academic practice. No use, distribution or reproduction is permitted which does not comply with these terms. 